\title{
Pain Control and Its Relationship with Histopathological Outcome in TRUS-Guided Prostate Needle Biopsy: A Prospective Non-Randomized Trial
}

\section{TRUS Eşliğinde Prostat Iğne Biyopsisinde Ağrı Kotrolü ve Histopatolojik Sonuçlarla Ilişkisi: Prospektiv ve Non-Randomize Çalışma}

\author{
Aslan Demir1, Kürşat Çeçen1, Mert Ali Karadağ1, Mehmet Uslu1, Ömer Erkam Arslan1, \\ Tufan Tarcan2
}

1 Kafkas University Faculty of Medicine, Department of Urology, Kars, Turkey

2 Marmara University Faculty of Medicine, Department of Urology, Istanbul, Turkey

\begin{abstract}
What's known on the subject? and What does the study add?
Pain during prostate biopsy is the most important problem which need a solution. The purpose of this study is to compare 3 pain control techniques and its relationship with pathology. According to our research in the literature, our study is the first study that investigate the relationship between pain level during prostate biopsy and the exist pathology in the patient.
\end{abstract}

\begin{abstract}
Objective

Transrectal ultrasound-guided prostate biopsy (TRUS-Bx) is a standard diagnostic modality for detecting prostate cancer (PCa). Pain during biopsy is the most important problem that still needs a solution. The purpose of this study was to compare 3 pain control techniques and to investigate the relationship between the level of pain and histopathological findings.
\end{abstract}

Materials and Methods

139 patients underwent prostate biopsy utilizing 3 analgesic techniques; 1- using lidocain gel (group 1), 2- pethidine+diazepam (group 2) and 3- periprostatic nerve block (group 3). Pain level, the tolerability and repetition of the procedure were questioned. The pathological findings were recorded.

\section{Results}

There was a statistically significant difference between group 1 and the others with regard to tolerability and repeating the procedure. The pain score during biopsy in group 1 was greater than in the other groups and those in group 2 was higher than in group 3 . The mean pain score during probe insertion in group 2 was lower than in groups 1 and 3 . The mean pain score taken during the biopsy was higher than that during probe insertion in group 2. However, the mean pain score during probe

\section{ÖZET}

Amaç

TRUS-biyopsi, prostat kanseri tanısında hala en kesin tanısal yöntemdir. Biyopsi esnasında oluşan ağrı ise başedilmesi gereken en önemli sorundur. $\mathrm{Bu}$ çalışmanın amacı, 3 farklı ağrı kontrol tekniği kıyaslamak ve ağrı düzeyi ile hastadaki mevcut patoloji arasındaki ilişkiyi araştırmaktır.

Gereç ve Yöntem

Yüz otuz dokuz hastaya, 3 farklı ağrı kontrol tekniği, kullanılarak prostat biyopsisi yapıldı. Gruplar sırasıyla; lidokain jel, petidin+diazepam, periprostatik sinir blokajı olarak belirlendi. Ağrı düzeyleri yanında, tolerabilite ve işlemi gerektiğinde tekrarlatma durumları sorgulandı. Patolojik sonuçlar kaydedildi.

\section{Bulgular}

Tolerabilite ve işlemi gerektiğinde tekrarlatma oranları arasındaki fark, grup 1'de diğer gruplara göre farklıydı. Ağrı skorları bakımından, grup 1 ve grup 2 diğer gruplardan istatistiksel olarak farklıydı. Prob yerleştirimi esnasındaki ağrı skorları, grup 2'de diğer gruplardan istatistiksel olarak anlamlı düzeyde farklıydı. Ayrıca, grup 2'de, biyopsi esnasında oluşan ağrı düzeyi skoru, prob yerleştirimi esnasındakinden daha fazlaydı. Ancak, grup 3 için prob yerleştirimi esnasında oluşan ağrı düzeyi skoru grup 1'dekinden farklı değildi. Gruplar arasında, patolojik sonuçlar açısından,

\section{Correspondence}

Aslan Demir MD, Kafkas University Faculty of Medicine, Department of Urology, Kars, Turkey

Phone: +90 53246582 25 E-mail: benaslandemir@yahoo.com.tr Received: 21.05.2015 Accepted: 22.05.2015

Presented in: 23th Turkish Urology Congress, 2014 


\section{ABSTRACT}

insertion in group 3 was not different from that in group 1. There was no significant difference in pathological results between group 1 and groups 2 and 3 . Pain scores in patients with chronic prostatitis were statistically higher than those in patients with benign prostatic hyperplasia (BPH) and Pca in groups 2 and $3(p<0.05)$.

\section{Conclusion}

Periprostatic nerve block is superior to the others. However, it is not better than pethidine plus diazepam during rectal probe insertion. In the presence of chronic prostatitis, pain scores can increase regardless of the pain control method.

\section{Key Words}

TRUS, prostate biopsy, histopathology, pain control

\section{ÖZET}

ağrı düzeyleri skorları farkı, grup 1 için anlamlı değildi. Kronik prostatitli hastaların ağrı skorları, grup 2 ve 3 'de, benign prostat hiperplazili (BPH) ve prostat kanserli hastalardan daha fazlaydı $(p<0,05)$.

\section{Sonuç}

Periprostatik sinir blokajı diğer 2 yöntemden daha üstündür. Fakat, rektal prob yerleştirimi esnasındaki ağrı skoru, petidin+diazepam grubundakinden daha iyi değildir. Kronik prostatit varlığıda, ağrı kontrol yönteminden bağımsız olarak ağrı düzeylerinin artmasının bir nedeni olabilir.

\section{Anahtar Kelimeler}

TRUS, prostat biopsisi, histopatoloji, ağrı kontrolü

\section{Introduction}

Transrectal ultrasound-guided prostate biopsy (TRUS-BX) is a standard diagnostic modality for detection of prostate cancer (Pca). Pain due to needle penetration of the prostatic capsule and discomfort due to probe insertion are the most important problems that need a solution, especially in case of repetitive procedures. In a study, $20 \%$ of patients who have undergone TRUS-Bx reported that they would not undergo a repeat biopsy procedure without any anesthesia (1). To solve this problem, several anesthetic techniques have been described, such as administration of lidocaine gel, periprostatic nerve blocks, nitrous oxide and oxygen inhalation, narcotic intramuscular medication, and intravenous sedation $(2,3,4)$.

Although the application of these techniques is somewhat effective, pain may not be optimally relieved during prostate biopsy. Another method of pain control is needed for anal discomfort. According to the best of our knowledge, there is no previous study in the literature about the use of a pethidine hydrochloride and diazepam combination. The purpose of this study was to evaluate the value and safety of pethidine hydrochloride in combination with diazepam compared to use of lidocaine gel or periprostatic nerve block alone.

\section{Materials and Methods}

This study was designed as a nonrandomized prospective study and was approved by the local ethics committee. Informed consent was obtained from all patients prior to biopsy. Male patients older than 50 years of age, who applied to our clinic for various complaints, underwent routine urine analysis, urine culture, total and free prostate-specific antigen (PSA) test and digital rectal examination (DRE). Between 2013 and 2014, a total of 139 patients underwent TRUS-Bx utilizing 3 different analgesic techniques, and 3 groups were formed according to the analgesic techniques; group 1 rectal administration of lidocaine gel to prostate, group 2 pethidine in combination with diazepam and group 3 periprostatic nerve block (PPNB). The groups were determined according to the history of clinical experience of our department. Namely, the first 41 patients were included in group 1, the latter 44 and 54 patients were included in group 2 and 3, respectively. All biopsies were performed by the same surgeon (AD).

\section{Inclusion Criteria}

Abnormal DRE suggesting prostate cancer; in case of high PSA levels (PSA $>2.5 \mathrm{ng} / \mathrm{dl}$ ), ongoing high PSA levels (PSA $>2.5 \mathrm{ng} / \mathrm{dl}$ ) sterile urine culture after antibiotic therapy in patients with suspicious chronic prostatitis (CP), and PSA velocity greater than $0.75 \mathrm{ng} / \mathrm{dL}$.

\section{Exclusion Criteria}

Anorectal disease (hemorrhoids, anal fissure or anal stenosis), recurrent urinary tract infection after antibiotic herapy, hypersensitivity to pethidine or diazepam.

\section{TRUS Biopsy Procedure}

Asingle dose intravenousciprofloxacin $750 \mathrm{mg}$ and phosphatidylcholine rectal enema were applied to all groups 2 hours before the biopsy. After providing cardiac monitoring, pulse oximetry, and blood pressure measurements, lidocaine gel administration was performed in the left lateral decubitus position to the perianal area for reducing anal pain during the insertion of rectal probe, and then, a transrectal probe was inserted. Prostate volume was calculated by using ellipsoid formula (heightxwidthxlengthx0.52). Findings were recorded and then TRUSbiopsy was applied by using an 18-gauge, $25 \mathrm{~cm}$ automatic biopsy device. A total of 12-core biopsy specimens were obtained. Pain level was determined using a visual analogue scale (VAS) at the end of the procedure. A VAS was used for pain assessment with a visual image of a straight line $10 \mathrm{~cm}$ in length that was scored from 0 (no pain) to 10 (worst possible pain). The patients were asked to mark the pain level at a point on the straight line (Figure 1). In addition, the tolerability of the procedure by the patients and the repetition of the procedure in case of need were questioned.

\section{Pain Control Methods (Group Characteristics)}

For the first group, lidocaine gel was applied to the prostate surface through rectum 5 minutes before the procedure. For the second group, intramuscular (i.m.) pethidine $(1 \mathrm{mg} / \mathrm{kg})$ was administered one hour before the procedure, and diazepam $(10 \mathrm{mg})$ infusion was provided during the biopsy. For the third group, a nerve block of 2 $\mathrm{mL} 1 \%$ lidocaine was injected just lateral to the junction between the prostate base and the seminal vesicle prior to the procedure. Proper placement of the needle was confirmed by observing a separation of seminal vesicles and prostate from the rectal wall on the ultrasonography (USG) screen. 


\section{Statistical Analysis}

This study was designed to detect a 30\% difference between the pain scores of the 2 methods with 90\% power assuming a significant difference level of 0.05 and two-sided statistical test. Depending on the results of a pilot study performed in our department dealing with the pain score of TRUS, we calculated the sufficient sample size for our study. All these stages were consulted with a biostatics specialist. The results are presented as mean \pm standard deviation (SD). Data were analyzed using SPSS-16.0 for Windows (SPSS, Inc., Chicago, IL USA). To determine the differences in pain levels between the 3 groups, oneway ANOVA was used. Univariate and multivariate analyses were used to compare the pain scores in terms of pathology between the groups. Pearson's correlation coefficient was used for correlation among variables. A probability level of $p<0.05$ was considered significant.

\section{Results}

There were no statistical differences in terms of age, body mass index (BMI), PSA, free/total PSA ratio, prostatic volumes that measured by transrectal ultrasonography (TRUS), and the pathologic results between the groups. The demographic characteristics of the study groups are summarized in Table 1.

The differences between BMI/NAS scores, BMI/PSA value, TRUS volume/ VAS scores and age/NAS scores were not statistically significant (Table 2).

The rates of the patients' tolerability in groups 1, 2 and 3 were $73.2 \%$, $100 \%$, and $100 \%$, respectively. The rates of the patients' consent for repeating the procedure in groups 1,2 , and 3 were $34.1 \%, 100 \%$, and $100 \%$, respectively. The difference between group 1 and the others was statistically significant with regard to tolerability and patient consent for repeating the procedure (Table 3).

The pain scores in groups 1,2 and 3 were $8.22 \pm 1.06,2.86 \pm 1.23$ and $2.17 \pm 1.4$, respectively. The pain score in group 1 was statistically greater than the pain scores in groups 2 and $3(p<0.05)$. The difference between group 2 and 3 was statistically significant ( $p<0.05$, Table 4).

There was a statistically significant difference in the mean pain scores at probe insertion between group 2 and groups 1 and $3(p<0.05$, Table 5). As expected, the mean pain score during biopsy $(2.86 \pm 1.23)$ was higher than that during probe insertion $(2.36 \pm 0.48)$ in group 2 . However, the mean pain score during probe insertion in group 3 was not different from that of group 1 ( $p=0.06$, Table 5$)$.

Pain scores with regard to pathological diagnosis in group 1 were $8.27 \pm 1.03,8 \pm 1.05$, and $8.33 \pm 1.22$, for $C P$, benign prostatic hyperplasia $(\mathrm{BPH})$ and Pca, respectively. No statistical difference was determined in terms of pathological results in group 1 ( $p>0.05$ ). Pain scores in group 2 with regard to the above mentioned pathological diagnoses were $3.35 \pm 0.98,2.4 \pm 1.4$, and $2.5 \pm 0.83$, respectively. Pain scores in group 3 were $3.29 \pm 1.21,1.65 \pm 1.19$, and $2.17 \pm 1.4$, respectively. The differences in pain scores in terms of pathological diagnoses between patients in group 1 were not statistically significant. Pain scores in patients with $\mathrm{CP}$ were statistically higher than those in patients with $\mathrm{BPH}$ and PCa in groups 2 and $3(\mathrm{p}<0.05$, Table 6$)$.

There were no statistical differences between the groups in terms of complications, including bleeding, infection, and acute urinary retention. However, although the differences between the groups were not statistically significant, the nausea rate in group 2 was slightly higher than in groups 1 and 3 . Complication rates were $0.7 \pm 0.46$, $0.27 \pm 1.02$ and $0 \pm 0$ in groups 1,2 and 3 , respectively $(p=0.098$ ).

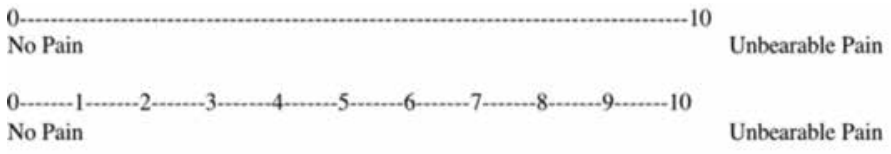

Figure 1. Visual analog pain scale

Table 1. The demographic characteristics of the groups

\begin{tabular}{|l|l|l|l|l|}
\hline Parameters & $\begin{array}{l}\text { Group 1 } \\
n=41\end{array}$ & $\begin{array}{l}\text { Group 2 } \\
n=44\end{array}$ & $\begin{array}{l}\text { Group 3 } \\
n=54\end{array}$ & $p$ \\
\hline Age (year) & $64.59 \pm 7.3$ & $66.5 \pm 7.2$ & $63.31 \pm 8.24$ & 0.128 \\
\hline BMI & $26.22 \pm 2.09$ & $25.71 \pm 3.33$ & $26.43 \pm 3.02$ & 0.462 \\
\hline PSA (ng/dL) & $9.84 \pm 4.94$ & $14.73 \pm 3.9$ & $9.25 \pm 4.84$ & 0.12 \\
\hline f/T PSA & $0.17 \pm 0.7$ & $0.18 \pm 0.08$ & $0.17 \pm 0.04$ & 0.65 \\
\hline $\begin{array}{l}\text { Prostate volume } \\
\text { (TRUS, cc) }\end{array}$ & $54.9 \pm 15.8$ & $57.72 \pm 22.69$ & $58.9 \pm 17.7$ & 0.58 \\
\hline $\begin{array}{l}\text { Chronic } \\
\text { Prostatitis }\end{array}$ & 22 & 20 & 17 & \\
\hline BPH & 10 & 18 & 31 & \\
\hline PCa & 9 & 6 & 6 & \\
\hline BMI: Body mass & PSA:prostate-spicantigen, BPH:beni prostac &
\end{tabular}

BMI: Body mass index, PSA: prostate-specific antigen, BPH: benign prostatic hyperplasia, $\mathrm{PCa}$ : prostate cancer

Table 2 . The pearson correlation coefficient between various parameters

\begin{tabular}{|l|l|l|}
\hline Parameters & Pearson Correlation Value & $p$ \\
\hline BMI-VAS scores & 0.008 & 0.924 \\
\hline BMI-PSA & -0.08 & 0.34 \\
\hline TRUS volume-VAS score & -0.038 & 0.65 \\
\hline Age-VAS score & -0.1 & 0.24 \\
\hline BMI: Body mass index, VAS: visual analogue scale &
\end{tabular}

Table 3 . The rates of tolerability and repeating the procedure

\begin{tabular}{|l|l|l|l|l|}
\hline & Group 1 & Group 2 & Group 3 & p \\
\hline $\begin{array}{l}\text { Relerability } \\
\text { Repeating the } \\
\text { procedure }\end{array}$ & $30(73.2 \%)^{*}$ & $44(100 \%)$ & $54(100 \%)$ & 0.001 \\
\hline
\end{tabular}

*Statistically significant difference compared to groups 2 and 3 Table 4 . The mean pain scores with standard deviation of 3 groups

\begin{tabular}{|l|l|l|l|l|}
\hline Pain scores & Group 1 & Group 2 & Group 3 & $p$ \\
\hline VAS scores & $8.22 \pm 1.06^{*}$ & $2.86 \pm 1.2^{* *}$ & $2.17 \pm 1.4$ & $\begin{array}{l}{ }^{*} p<0.001 \text {, between group1 and group 2 with 3 } \\
\text { **p }<0.02 \text {, between group 2 and group 1 with 3 }\end{array}$ \\
\hline
\end{tabular}


Table 5 . The mean pain scores with standard deviation during rectal probe insertion

\begin{tabular}{|l|l|l|l|l|}
\hline & Group 1 & Group 2 & Group 3 & $p$ \\
\hline Pain scores & $4.46 \pm 0.5$ & $2.36 \pm 0.48^{*}$ & $4.72 \pm 0.6$ & 0.000 \\
\hline \multicolumn{5}{|l}{ * Statistically significant difference compared to groups 1 and 3 $(p<0.000)$} \\
\hline
\end{tabular}

Table 6 . The mean pain scores with standard deviation in regard to pathological results

\begin{tabular}{|l|l|l|l|l|}
\hline Groups & Chronic Prostatitis & $\mathrm{BPH}$ & $\mathrm{PCa}$ & $\mathrm{p}$ \\
\hline Group 1 & $8.27 \pm 1.03$ & $8 \pm 1.05$ & $8.33 \pm 1.22$ & $>0.05$ \\
\hline Group 2 & $3.35 \pm 0.98^{*}$ & $2.4 \pm 1.4$ & $2.5 \pm 0.83$ & $<0.05$ \\
\hline Group 3 & $3.29 \pm 1.21^{*}$ & $1.85 \pm 1.19$ & $2.17 \pm 1.4$ & $<0.05$ \\
\hline $\begin{array}{l}\text { BPH: benign prostatic hyperplasia, PCa: prostate cancer } \\
{ }^{*} \text { Chronic prostatitis is different from BPH and PCa in groups 2 and 3 }\end{array}$ \\
\hline
\end{tabular}

\section{Discussion}

The need for a prostate biopsy is determined according to PSA level and/or a suspicious DRE (5). However, in some situations, including a rising and/or persistent elevated PSA, suspicious DRE (despite benign biopsy result, 5-30\% risk of cancer), atypical small acinar proliferation (ASAP, 40\% risk of cancer) (6), and extensive prostatic intra-epithelial neoplasia (PIN, 20-30\% risk of cancer), a repeat biopsy is needed, and in some special situations, a saturation biopsy ( $>20$ cores) is needed (5). For that reason, a good pain control is mandatory, especially in order to prevent patient's refusal to repeat biopsy. Some studies have showed that about $20 \%$ of patients who underwent biopsy would reject rebiopsy without any kind of analgesia (7). According to our results, the rate of tolerability in group 1 was about $73.2 \%$ and the rate of patient consent for repeating the procedure was about 34.1\% in the same group. This result showed that $66 \%$ of patients, in whom adequate pain control is not achieved, would refuse the rebiopsy procedure in case of need. As opposed to these results, all patients in group 2 and 3 tolerated the procedure and the repeating rate was $100 \%$ in both groups in case of need.

Although the best method of pain control for prostate biopsy has not yet been defined, several techniques have been introduced in the literature such as local application of lidocaine gel alone, periprostatic nerve block, oral administration of different kinds of nonsteroidal antiinflammatory drugs, intravenous or suppository sedation with fentanyl and pelvic plexus block or intraprostatic local anesthetic injections, or combinations of these methods $(8,9,10,11,12,13)$. In addition to these, one of the issues is discomfort and pain during probe insertion. According to Tsuji et al., the mean pain score was $2.73 \pm 2.55$ during probe insertion under sedoanalgesia with midazolam and fentanyl citrate (14). Griwan et al. showed that the mean pain score during the placement of the rectal probe was $4.85 \pm 1.09$ under diclofenac pain control (15). According to our study, the mean pain scores during the rectal probe insertion were $4.46 \pm 0.505,2.36 \pm 0.48$, and $4.72 \pm 0.6$, in groups 1, 2, and 3, respectively. The main difference between our work and the study of Tsuji et al. is in the anesthesia technique (14). Their pain score was lower than ours, but their technique needs an anesthetist and longer hospital stay, besides, complications may occur depending on sedoanalgesia. The results of the study of Griwan et al. are similar to ours. According to our results, the mean pain score in the pethidine plus diazepam group was significantly different than in lidocaine gel and periprostatic nerve block groups (15). This result may be due to relaxation of anal tonus by means of diazepam. Although periprostatic nerve block provided good pain control during biopsy, the mean pain score was not different from that of group 1. This result can be due to the pain during probe insertion before applying periprostatic block. We concluded that the mean pain scores during probe insertion were similar unless anal tonus relaxation was provided before the anesthesia method.

According to our results, the main pain score during prostate biopsy in group 3 was similar to that in the study by Akpınar et al., i.e. $2.17 \pm 1.4$ vs $2.05 \pm 1.01$. However they achieved this result by pelvic plexus block (9). We concluded that there is no significant difference between periprostatic nerve block and pelvic plexus block for providing a good pain control for prostate biopsy procedure. In accordance with our study, pain control with periprostatic nerve block (group 3) was much better than that with pethidine plus diazepam (group 2) ( $p=0.02$, Table 4). However, both techniques were rather tolerable by the patients. On the other hand, pain control during probe insertion was much more successfully achieved in group 2 (pethidine plus diazepam group).

One of the most important issues that we investigated was the relationship between pain control method and pathological diagnosis. According to our research, our study was the first one that investigated whether the pathology type affected mean pain scores or not (CP, $\mathrm{BPH}$ and $\mathrm{PCa}$ ). Our results showed that the effect of local anesthesia was the worst in case of CP (Table 6). This situation can be taken into consideration especially in case of rebiopsy if the first pathology is reported as $\mathrm{CP}$.

Tsuji et al. showed that pain scores were not correlated with age and prostate volume (14). These results are similar to ours. We did not find any additional correlation of BMI and PSA with pain scores $(p<0.005$, Table 2).

There was no statistical difference between the groups in terms of complications including bleeding, infection, and acute urinary retention. However, the nausea rate was slightly higher in group 2 than in groups 1 and 3. Complication rates in groups 1, 2 and 3 were $0.7 \pm 0.46,0.27 \pm 1.02$ and $0 \pm 0$, respectively $(p=0.098)$. Acute urinary retention was observed in only one patient in group 1 whose pathological diagnosis was reported as CP.

\section{Weak Parts of the Study}

According to our first plan, 50 patients would be included in each group. However, according to our initial results, some patients could not tolerate pain, especially those in the first group. For that reason, the number of patients in the groups changed.

\section{Conclusion}

Although periprostatic nerve block is superior to the application of lidocaine gel or pethidine in combination with diazepam during biopsy procedure, it is not better than pethidine in combination with diazepam at the onset of the procedure during rectal probe insertion. In case of the presence of chronic prostatitis, pain scores can increase regardless of the pain control method. 
Ethics Committee Approval: The local ethics committee was approved.

Informed Consent: Informed consent was obtained from all patients.

Concept: Aslan Demir

Design: Aslan Demir

Data Collection or Processing: Mehmet Uslu, Ömer Erkam Arslan

Analysis or Interpretation: Aslan Demir, Mert Ali Karadağ, Kürşat Çeçen

Literature Search: Aslan Demir, Mert Ali Karadağ, Kürşat Çeçen, Mehmet Uslu, Ömer Erkam Arslan

Writing: Aslan Demir, Mert Ali Karadağ, Tufan Tarcan

Peer-review: Internal peer-reviewed.

Conflict of Interest: No conflict of interest was declared by the authors.

Financial Disclosure: The authors declared that this study has received no financial support.

\section{References}

1. Collins GN, Lloyd SN, Hehir M, McKelvie GB. Multiple transrectal ultrasound-guided prostatic biopsies-true morbidity and patient acceptance. Br J Urol 1993;71:460-463.

2. Medina MC, Cadena GY, Guerra GA, Hidalgo PJM. Local anesthetic versus ultrasound-guided lidocaine enjection for pain control in patients undergoing prostate biopsy. Actas Urol Esp 2006;30:987-990.

3. Pareek G, Armenakas NA, Fracchia JA. Periprostatic nerve blockade for transrectal ultrasound guided biopsy of the prostate: a randomized, double blind, placebo controlled study. J Urol 2001;166:894-897.

4. Young $A$, Ismail M, Papatsoris AG, Barua JM, Calleary JG, Masood J. Entonox inhalation to reduce pain in common diagnostic and therapeutic outpatient urological procedures: a review of the evidence. Ann R Coll Surg Engl 2012;94:8-11.

5. Mottet $N$, Bastian PJ, Bellmunt J, Van der Bergh RCN, Bolla $M$, van Casteren NJ, Cornford P, Joniou S et al. Guidelines on Prostate Cancer 2014;page19-20.
6. Epstein Jl, Herawi M. Prostate needle biopsies containing prostatic intraepithelial neoplasia or atypical foci suspicious for carcinoma: implications for patient care. J Urol 2006;175:820-834.

7. Singh SK, Kumar A, Griwan MS, Sen J. Comparative evaluation of periprostatic nerve block with and without intraprostatic nerve block in transrectal ultrasound-guided prostatic needle biopsy. Korean J Urol 2012;53:547-551.

8. Anup K, Pawan V, Niraj K, Biswajit, Nayan MK. A prospective randomized trial comparing three different analgesic techniques for pain control during transrectal ultrasound guided biopsy: a single center experience. Minerva Urol Nephrol 2013;65:77-82.

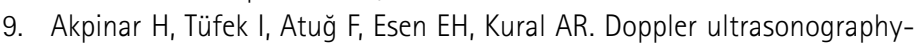
guided pelvic plexus block before systematic needle biopsy of the prostate: A prospective randomized study. Urology 2009;74:267-271.

10. Cantiello F, Cicione A, Autorino R, Cosentino C, Amato F, Damiano R. Pelvic plexus block is more effective than periprostatic nerve block for pain control during Office transrectal ultrasound guided prostate biopsy: a single center, prospective, randomized, double arm study. J Urol 2012;188:417-421.

11. Maccagnano C, Scattino V, Roscigno M, Raber M, Angiolilli D, Montorsi $F$, Rigatti P. Anaesthesia in transrectal prostate biopsy: which is the most effective technique? Urol Int 2011;87:1-13.

12. Binggian L, Peihuan L, Yudong $W_{1}$ Jinxing $W_{1}$ Zhiyong W. Intraprostatic local anesthesia with periprostatic nerve block for transrectal ultrasound guided prostate biopsy. J Urol 2009;182:479-483.

13. Cevik I, Dillioglugil O, Zisman A, Akdas A. Combined "periprostatic and periapical" local anesthesia is not superior to "periprostatic" anesthesia alone in reducing pain during Tru-cut prostate biopsy. Urology 2006;68:1215-1219.

14. Tsuji FH, Chambo RC, Agostinho AD, Filho JCST, de Jesus CMN. Sedoanalgesia with midazolam and fentanyl citrate controls probe pain during prostate biopsy by transrectal ultrasound. Korean J Urol 2014;55:106-111.

15. Griwan MS, Kumar A, Sen J, Singh SK. Comparative evaluation of periprostatic nerve block and diclofenac patch in Transrectal Ultrasoundguided prostatic Needle biopsy. Nephrourol Mon 2012;4:560-564. 